\title{
THE TACTICAL URBANISM IN INDONESIAN CITY SPACES DURING THE COVID-19 PANDEMIC
}

\author{
Wakhidah Kurniawati ${ }^{1}$ \\ ${ }^{1}$ Departemen Perencanaan Wilayah dan Kota, Universitas Diponegoro \\ Email: wakhidahkurniawati3@gmail.com
}

\begin{abstract}
Abstrak
The Covid-19 pandemic has changed the world order in all aspects of life. City space that was considered successful if it can accommodate residents' crowded activities has become deserted because of the lockdown and health protocols implementation. The meaning of urbanism is challenged because new interaction is put in place. Urban space activity adapts to new patterns and creates modified spaces. Tactical urbanism is one of the flexible design responses in the urban area to support the long-term goal of improving urban space quality. Tactical urbanism is currently being applied in several cities around the world in response to the Covid-19 pandemic. Urban space in Indonesia also applies tactical urbanism with Indonesian characteristics. This study aims to examine the implementation of tactical urbanism in Indonesian urban spaces. The method used is reviewing data from online publications published between March 2020 - March 2021 regarding tactical urbanism in urban spaces in Indonesia. The city space chosen is located in the urban kampung, traditional market, and a downtown public space. The result shows two patterns of tactical urbanism in urban areas in Indonesia during the pandemic era, namely reactive and momentary response in urban kampong and traditional market, and unified response with city planning in bike lanes program..
\end{abstract}

Kata kunci: tactical urbanism, public space, Covid-19 pandemic

\section{BACKGROUND}

The COVID-19 pandemic has forced cities around the world to adapt to health protocols. Urban spaces are experimenting with meeting the needs of activities by paying attention to maintaining the distance, accommodating rapid changes due to the pandemic, and supporting local economic activities and healthy habits (Honey-Roses et al., 2020). Tactical urbanism is an action to implement a transformative and adaptive response to existing challenges, including the COVID-19 pandemic, even by street art (Metropolis, 2020; Moser et al., 2020; parcitipatory, 2020).

Urbanism is a way of life (Wirth, 1938), but sometimes it is not easy to intervene in the public space as connecting space in urban life due to the bureaucratic and high cost in improving. Especially the improvement for unpredictable forces such as the COVID-19 pandemic.

Meanwhile, tactical urbanism is a shortrange act for an enduring transformation (Lydon et al., 2012). Usually, it low-priced, simple, instant solutions with a tactic behind (Pfeifer, 2013). "...Tactic means it has a vision, a local context, a short-term commitment, a low-risk and high-reward value and the support of a community and develops social capital by bringing neighbours together...". There are several examples of tactical urbanism, such as popup bike lanes during the Covid-19 pandemic and managing the physical distancing by colour, line, and sign. Tactical urbanism is also famous as doing it yourself (DIY) urbanism, guerrilla urbanism or pop- 
up urbanism (Pfeifer, 2013). Inspired by Paris, then several cities in the world applied this tactic.

Bogota applied numerous initiatives in public space, especially in open 47 miles bicycling track as healthy and hygienic mobility (Hakimizadeh, 2020). Cities in Italia use the new type of mobility program, such as smart move in Genoa, sustainable urban mobility program in Bologna, and new bike lanes and sharing mobility in Florence (Barbarossa, 2020). So do other cities in the world applying tactical urbanism in their urban space.

Indonesia has several cities which applying tactical urbanism embedded with each city characteristic. Then, this research wants to scrutinise the type of tactical urbanism in Indonesia by exploring the online data in one year of pandemic. The expected result is patterns of tactical urbanism in urban areas in Indonesia during the pandemic era.

\section{METHODS}

This study aims to examine the implementation of tactical urbanism in Indonesian urban spaces. The method used is the review of data from online publications published between March 2020 - March 2021 regarding the application of tactical urbanism in urban spaces in Indonesia. The online data publication is in the form of the trusted website, online newspaper, magazine, webinar presentation, scientific data from research and journal. The verification of the data will be checked by triangulation with several sources.

\section{ANALYSIS}

It is more than a year since discovering the Covid 19 case in Indonesia in March 2020. Today, in April 2021, Indonesia is in the 20th position of Covid cases globally, with the number of positive instances above 1.5 million people. See Figure 1.

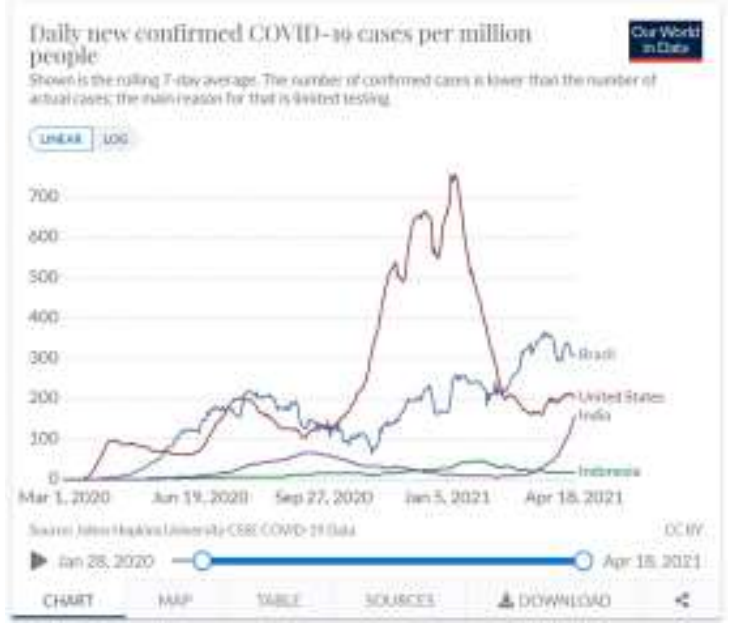

Figure 1. The case of Covid-19 in the world and Indonesia per April 182021

(Source: Our World in Data, 2021)

The Large-Scale Social Restriction Policy (Pembatasan Sosial Berskala Besar-PSBB) in mid-2000 and the Restriction of Community Activities (Pembatasan Kegiatan Masyarakat Mikro-PPKM) in early 2021 received different responses in urban spaces. In several urban kampongs, the inhabitants responded with community cooperation or even locking the kampong from outsiders to fortify the area from the pandemic.

In formal trading centres, the implementation of health protocols begins with restrictions on shop opening times, provision of hand sanitisers, rules for wearing masks, and queuing at a distance when paying at the cashier. In traditional markets, rapid testing is often applied, but only a few markets apply the physical distance for traders.

In public spaces, provision space for cyclists, hand washing stations, guidelines and signs to maintain physical distancing are always placed in downtown public areas. Street vendors are also regulated by their trading time. These are the transient responses of the city in facing the pandemic. This quick, inexpensive, and participatory response from the 
community is known as tactical urbanism (Pine, 2020).

\section{Tactical Urbanism in Urban Kampong}

Urban Kampong is a unique and sporadic settlement in Indonesia which is applying togetherness in everyday life. As part of informal settlement, several urban kampongs have limited infrastructure, high-density building, crowded activities due to the sharing space for work and domestic activities in the street alley, and engender urban kampong as a vulnerable place for spreading viruses in the pandemic. In the first implementation of PSBB in 2020, several kampongs responded to this regulation reactively. Several kampongs were locking the main entrance from outsiders. They used portal, banner, fencing their settlement for lockdown reason. They used banner and speaker to remind people of physical distancing, wear the mask, and wash the hands. They used non-fix material such as bamboo to fortify their territory from the outsider. Some kampongs use security space (gardu pos) as a checkpoint for noninhabitant to enter the kampong. So that peddlers and online motorcycle taxis cannot enter any kampongs anytime.

They put portable handwash near the gate of the kampong. Some people take turns guarding the main entrance to diminish the influx of non-resident. To reduce boredom and to improve health, sometimes they do sport together in the street alley. People in kampong create a temporary adaptation for pandemic using low cost and non-fix material to cut guests pass in kampong territory. They applied simple and spontaneous tactical urbanism to reduce the virus COVID-19 spreading.

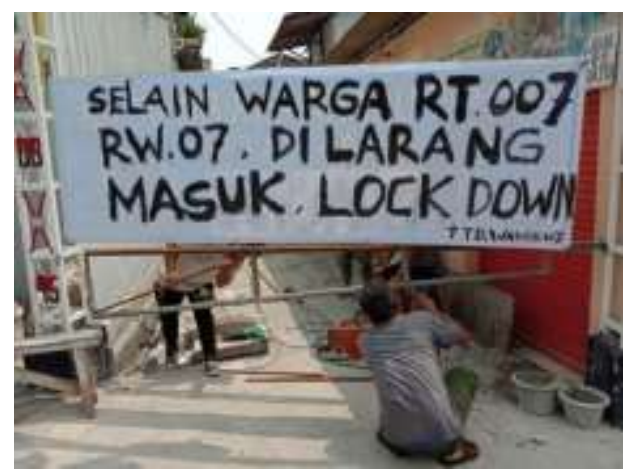

Figure 2. Tactical Urbanism in Urban Kampong (1)

(Source: rujak.org, 2020)

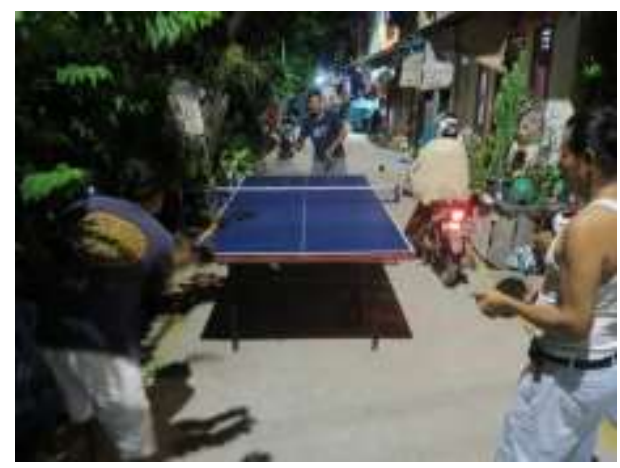

Figure 3. Tactical Urbanism in Urban Kampong (2)

Source: rujak.org, 2020

\section{Tactical Urbanism in Traditional Market}

The traditional market is a melting pot of people shopping, trading, doing recreation, and interacting with others. This place is vulnerable to the virus spreading due to the crowding, no physical distancing, indoor, lack of light and air, and absence of cleanliness. Some cities considered this situation and tried to solve the problem by arranging the traditional market in the pandemic era. In the morning market in Salatiga City, physical distancing for trader was applied by placing the distance by sign. The local government closed the main road in front of the traditional market in the morning to allocate the traders here. They put the box marks on the road, and traders should 
place themselves in the provided space. This arrangement does not disturb the traffic due to this morning market open daily from midnight until 06.00 AM. This procedure was first applied on April 27 2020 , as the local government respond to

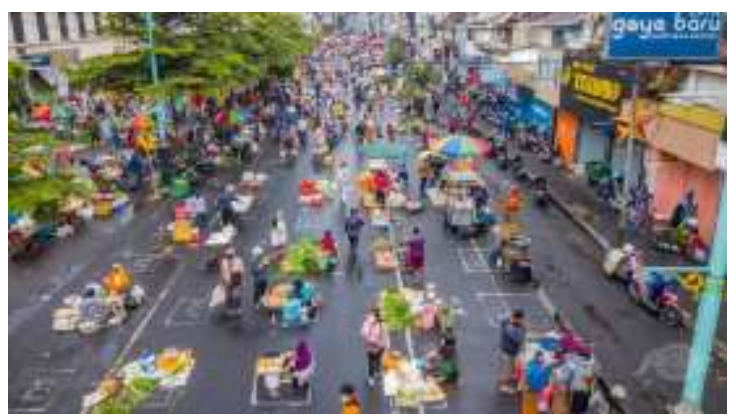

Figure 4. The Tactical Urbanism in the Morning Market in Salatiga City, Indonesia (Source: news.detik.com, 2020)

\section{Tactical Urbanism in Public Space}

\section{A. Bike lanes in Pandemic Era}

The application of tactical urbanism in the cities in the world is common today, likewise in Indonesian cities. Due to the increase in bicycle users tenfold or $1.000 \%$ during the PSBB in a pandemic in urban areas compared with the cyclist in October 2019 (ITDP,2020 in Wibowo, 2020), the government should provide bicycle lanes. In Jakarta, the government already proposed to build $578 \mathrm{~km}$ bike tracks for 2030 (Arbi, 2021). Meanwhile, for this year, the target for bicycle path is $\mathbf{1 0 1 . 2}$ kilometres, consisting of 34.1 kilometres of protected bicycle paths, and 87.1 kilometres is unprotected or shared with other road users (Amalia, 2021).

And today, as a response to the increasing number of cyclists in the pandemic era, cyclists are spoiled by the construction of 11.2 kilometres permanent bicycle lanes along Sudirman-Thamrin Street with a bike rack facility as a bicycle rest area. The divider is a type of flower pot or planter box that connects like a chain. Meanwhile, there are permanent bike tracks in pedestrian ways using green colour in maintain a healthy and resilient economy in the pandemic era (Purbaya, 2020).

This model is also practiced in 13 traditional markets in Central Java Province. In Bintoro morning Market, Demak City, 110 boxes marks with $2 \times 2$ meters are provided for traders.

several places, such as in Sudirman Street. So, in the Jakarta case, the government uses tactical urbanism to support bike lanes in main road or pedestrian ways by separation or colour. See Figure 5.

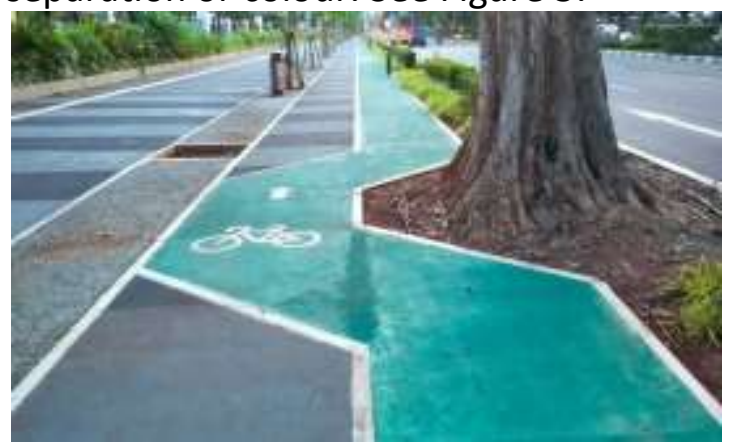

Figure 5. Tactical Urbanism for Bicycle Lanes in Jakarta (1) Source: gempita.co, 2021

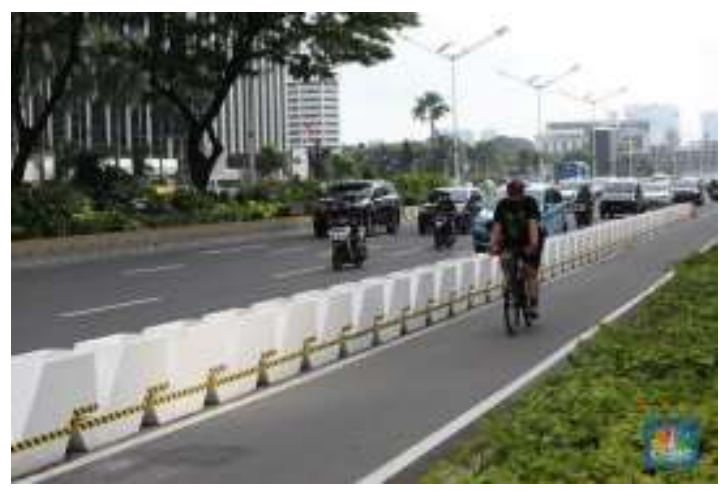

Figure 6. Tactical Urbanism for Bicycle Lanes in Jakarta (2) Source: CNBC Indonesia, 2021

\section{B. Physical Distancing in Public Space}

In today pandemic era, physical distancing is the most important thing to do to lessen the COVID-19 virus spreading. The government put the sign in public space to remind people to be aware of physical distancing. The sign in geometric shape, such as rings in Sempur Park, Depok and boxes in the traditional market, or put 
stickers, masking tape, and place warning sign in public bench, queue line, place of prayer (sholat) in the mosque, and even drive-in concert. Absolutely, tactical urbanism is only a tool for arranging people to behave well in a pandemic era suitable with health protocol. But, without supervision and sanctions, sometimes it is easy to break the rule.

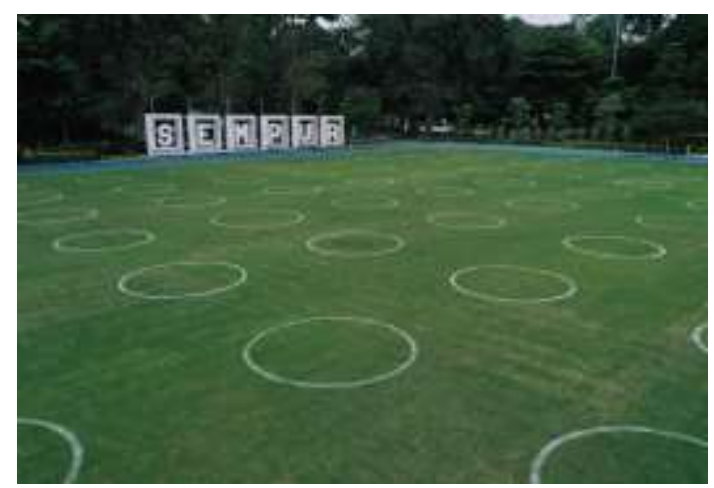

Figure 7. Tactical Urbanism in Sempur Park

Source: Kompas Image, 2020

\section{RESULT AND RECOMMENDATION}

Based on the discussion above, we can conclude that tactical urbanism in Indonesia has its characteristic, namely: non-fix element, temporary actions, and may disappear after the pandemic. Several types of tactical urbanism in Indonesia depend on location and space function. See Table 1.

Table 1. Tactical Urbanism in Indonesia

\begin{tabular}{clll} 
No & $\begin{array}{c}\text { Space } \\
\text { Use }\end{array}$ & \multicolumn{1}{c}{$\begin{array}{c}\text { Elements } \\
\text { Used }\end{array}$} & $\begin{array}{c}\text { Type of } \\
\text { tactical } \\
\text { urbanism }\end{array}$ \\
\hline 1. $\begin{array}{l}\text { Urban } \\
\text { Kamp }\end{array}$ & $\begin{array}{l}\text { Portal, } \\
\text { banner, }\end{array}$ & $\begin{array}{c}\text { - low cost } \\
\text { and non- } \\
\text { ong } \\
\text { fence, } \\
\text { banner, }\end{array}$ & fix \\
& material \\
& bamboo, & - simple \\
& security & and \\
& space, & spontaneo \\
& street alley & us tactical \\
& as a sport & urbanism \\
& area &
\end{tabular}

\begin{tabular}{|c|c|c|c|}
\hline 2. & $\begin{array}{l}\text { Tradit } \\
\text { ional } \\
\text { Mark } \\
\text { et }\end{array}$ & $\begin{array}{l}\text { Boxes sign } \\
\text { for traders }\end{array}$ & $\begin{array}{l}\text { - Non- } \\
\text { permanen } \\
\text { t boxes } \\
\text { mark }\end{array}$ \\
\hline 3. & $\begin{array}{l}\text { Public } \\
\text { Space }\end{array}$ & $\begin{array}{l}\text { - Bike lanes } \\
\text { with } \\
\text { separation } \\
\text { or colour } \\
\text { - Mark } \\
\text { signs for } \\
\text { physical } \\
\text { distancing }\end{array}$ & $\begin{array}{l}\text { - The } \\
\text { separation } \\
\text { is a type } \\
\text { of flower } \\
\text { pot or } \\
\text { planter } \\
\text { box } \\
\text { - The sign in } \\
\text { geometric } \\
\text { shape }\end{array}$ \\
\hline
\end{tabular}

Source: Analysis, 2021

From the above table, it could be concluded that tactical urbanism in Indonesia is a reactive response. For the non-fix material and the type of elements used in urban kampong and traditional market, may tactical urbanism is not for a longer time, just for a short time, like a momentary trend. And maybe it does not change the lifestyle and habit after the pandemic era. For cyclists' bike lanes, this tactical urbanism is the unified response with transportation planning in Jakarta; this action may more sustain due to the support from the government and new paradigm to apply a healthy lifestyle.

\section{ACKNOWLEDGEMENT}

Special thanks to R. Rafii Bisatya Rahmat, ST, for handling the appearance of the article.

\section{REFERENCES}

Amalia, Y. (2021). Upaya Anies Baswedan Manjakan Pesepeda di Jakarta. Merdeka.Com.

https://www.merdeka.com/jakarta/upaya -anies-baswedan-manjakan-pesepeda-dijakarta.html

Arbi, I. A. (2021). Anies: 578 Kilometer Jalur Sepeda Ditargetkan Selesai pada Tahun 
2030. Kompas.Com. https://megapolitan. kompas.com/read/2021/02/27/14363461 /anies-578-kilometer-jalur-sepedaditargetkan-selesai-pada-tahun2030?page=all

Barbarossa, L. (2020). The Post Pandemic City: Challenges and Opportunities for a Non-Motorized Urban Environment. An Overview of Italian Cases. Sustainability, 12(17), 7172.

Hakimizadeh, L. (2020). The Rise of "Slow Streets" in Pandemic Era. Linkedin.Com. https://www.linkedin.com/pulse/riseslow-streets-pandemic-era-leilahakimizadeh-aicp-leed-ap-nd-1c/

Honey-Roses, J., Anguelovski, I., Bohigas, J., Chireh, V., Daher, C., Konijnendijk, C., \& others. (2020). The Impact of COVID-19 on Public Space: A Review of the Emerging Questions [Internet]. Open Science Framework; 2020 Apr [cited 2020 May 22]. https://doi.org/https://doi.org/10.31219/ osf.io/rf7xa

Lydon, M., Bartman, D., Woudstra, R., \& Khawarzad, A. (2012). Tactical Urbanism: Short-term action Long-term change (Vol. 1). https://issuu.com/streetplanscollaborative/docs/tactical_urbanism_vol.1

Metropolis. (2020). Tactical Urbanism as a response during the pandemic. Metropolis.Org.

https://www.metropolis.org/news/ tactical-urbanism-response-duringpandemic

Moser, B., Malzieu, T., \& Petkova, P. (2020). Tactical Urbanism: Reimagining Our Cities post-Covid-19. Fosterandpartners.Com.

https://www.fosteran dpartners.com/plus/tactical-urbanism/
Oktaviano, D. (2020). Penampakan Lingkaran Pembatas Warga di Lapangan Sempur Bogor. Kompas.Com. https://foto.kompas.com/photo/read/202 0/6/13/1592057784bad/1/penampakanlingkaran-pembatas-warga-di-lapangansempur-bogor

parCitypatory. (2020). Tactical Urbanism: Creating Long-Term Change in Cities Through Short-Term Interventions. Parcitypatory.Org.

https://parcitypatory.org/2020/07/31/tac tical-urbanism/

Pfeifer, L. (2013). The planner's guide to tactical urbanism. Montereal, Canada Page.

Pine, J. (2020). The Case for Tactical Urbanism in the Age of Coronavirus. Strongtowns.Org.

https://www.strongtowns.org/journal/20 20/4/6/tactical-urbanism-coronavirus

Purbaya, A. A. (2020). Keren! Penampakan Pasar Pagi Salatiga Terapkan Physical Distancing. News.Detik.Com. https:// news.detik.com/berita-jawa-tengah/d4994563/keren-penampakan-pasar-pagisalatiga-terapkan-physical-distancing

Ritchie, H., Ortiz-Ospina, E., Beltekian, D., Mathieu, E., Hasell, J., Macdonald, B., Giattino, C., Appel, C., \& Roser, M. (2021). Statistics and Research Coronavirus (COVID-19) Cases. Ourworldindata.Org. https://ourworldindata.org/covid-cases

Sabki, M. (2021). Dear Pesepeda, Intip Jalur Permanen Sepeda Sudirman-Thamrin. Cnbcindonesia.Com. https://www.cnbc indonesia.com/lifestyle/2021022618555834-226525/dear-pesepeda-intip-jalurpermanen-sepeda-sudirman-thamrin/6

Sarafil, J. (2021). Jalur Sepeda Permanen 
Sepanjang Sudirman-Thamrin Jakarta akan Dibagun. Gempita.Co. https://gempita.co /jalur-sepeda-permanen-sepanjangsudirman-thamrin-jakarta-akan-dibagun/

Wibowo, E. A. (2020). Pesepeda Indonesia Naik 1000 Persen, Negara Ini Alami Lonjakan. Otomotif.Tempo.Co. https://otomotif. tempo.co/read/1361580/pesepedaindonesia-naik-1000-persen-negara-ini-alamilonjakan

Widiachristy, L., \& Sutanudjaja, E. (2020). Tanggap dan Adaptasi pada Kampung Kota di Era Pandemik. Rujak.Org. https://rujak.org/tanggap-dan-adaptasipada-kampung-kota-di-era-pandemik/

Wirth, L. (1938). Urbanism as a Way of Life. American Journal of Sociology, 44(1), 1-24. 